in the administration of everything pertaining to pensions, benefits, claims and similar matters.

A repository and clearing house for the records of war agencies, draft and ration and similar boards in Iowa, already directed by the war department to be sent to the state capital, for which no place is now available.

Fulfillment of the idea of the Iowa department G. A. R. over thirty years ago for "A Grand Army Corridor," or something similar, for the preservation of all Iowa war records-the same thought frequently and more recently expressed.

Doing substantially that which was embraced in the official plat of the capital grounds twenty-five years ago when the law designated location for precisely the kind of building now proposed, as a necessary addition to the plant of the state for the transaction of public business with special emphasis on historical, legal and educational service.

The state would more fully satisfy the desires of many thousand people of Iowa, young and old, from every county of the state, who visit the state historical building, for study, for information and for understanding of the history of Iowa and of Iowa people. In this way only can Iowa maintain its well earned reputation for leadership in these vital matters.

\title{
SUPREME COURT SERIES ENDS
}

With the group of biographical sketches and portraits of Iowa Supreme Court Justices appearing in this number of THE ANNALS the series continuing through this volume is at an end. All individual justices serving for either long or short periods upon the court have been presented. The whole group shown from the July 1944 issue to the present constitute a noteworthy aggregation of prominent and able Iowa attorneys who attained sufficient standing in their profession to be elected to serve upon the highest court of the Hawkeye state.

The editor of THE ANNALS is gratified to be able to include this important chapter in the history of Iowa to its 
readers, and was able to do so through the courtesy of former Justice Frederick F. Faville, now code editor and reporter of the Supreme Court of Iowa and his assistant, Mr. Wayne A. Faupel.

The series has proven a popular feature of THE ANNALS throughout the year, during which period extra sheets of that section of our publication have been printed and now will be bound in pamphlet form and issued by the code editor, and may be obtained from him or the State Printing Board.

\section{AN EARLY LEGISLATIVE LIST}

Statistics relative to the Ninth General Assembly, of the State of Iowa, and the State departments, civil and military. This is the pretentious title of unpretentious pamphlet of sixteen pages, by Ed. B. Stillman, compiler, printed in 1862. The compiler explains that a previous legislature had provided for the printing of "a legislative compendium," but failed to provide the money therefor. However, he had made out a list and printed same.

Some features are different from the present day customs. For instance, in the list of members of the General Assembly the weight of each and every one is given. Probably in view of the then approaching era of hostilities, much stress was laid on the size of men in the public service. A survey of the list shows that while Gov. Samuel J. Kirkwood weighed 191 pounds, his adjutant general. Nathaniel B. Baker, weighed 200 pounds. Other weights recorded were: Elijah Sells, secretary of state, 175 ; J. W. Cattell, auditor, 180 ; John W. Jones, treasurer, 225. There was failure to find out the weight of either of the three justices of the supreme court.

In the House of Representatives W. E. Woodworth of Henry county was listed as weighing only 112 pounds, while near him sat M. Price of Muscatine, 245. In the Senate, there was G. W. McCrary of Lee, weight 100, and in the same body M. V. Burdick of Winneshiek carrying 235 pounds. 
Copyright of Annals of Iowa is the property of State of Iowa, by \& through the State Historical Society of Iowa and its content may not be copied or emailed to multiple sites or posted to a listserv without the copyright holder's express written permission. However, users may print, download, or email articles for individual use. 